\title{
SpeCial SeCtion Guest EDITORIal
}

\section{Pioneers in Biomedical Optics: Special Section Honoring Professor Watt Webb, Cornell University}

Professor Watt W. Webb of Cornell University has made tremendous contributions to the field of biological physics, and many of these fall under the mantle of biomedical optics. These contributions include the developments of new techniques and seminal research results, as well as voluminous training of rigorous biophysicists at both the graduate student and postdoctoral levels. As is the case for most senior biological physicists, Prof. Webb began his career in a more traditional area of physics (metallurgical physics) and transitioned to biological research during his midcareer. His long record of productive research continues today, and a visitor to his laboratories in Clark Hall will still find a nontrivial group of young scientists training to be the future leaders of biological physics.

Prof. Webb was obviously born for his chosen career in experimental physics. After all, the Webb family motto, "Tentanda via est," means "to experiment is the true way." Thus, it seems no coincidence that he would become known for his exquisite experiments and the underlying biological truths that they reveal. He attended the Massachusetts Institute of Technology (MIT), where he received both his bachelor's and doctorate degrees. He worked as an industrial physicist for Union Carbide in between the BS and ScD, and then returned there for another six years after finishing his doctorate. He then moved to Cornell University, the institution that he often refers to as "that upstate New York cow college," and this would remain his home for more than 40 years. At Cornell University, Webb joined the relatively young School of Applied and Engineering Physics, which he would also head from 1983 to 1989. Since 1998, he has been the S.B. Eckert Professor in Engineering.

In Ithaca, he and his wife, Page, raised their three sons, who have all gone on to successful careers in various fields: Buck is a physicist with IBM working on magnetic memory, Spahr is a geophysicist working on deep-ocean science at the Lamont-Doherty Earth Observatory of Columbia University, and Watt III is an investment advisor in Southern California. Of particular importance, though, is the support from Page. All of us in science know how important it is to have understanding, patience, and support for our careers at home. It has been said that she "took care of Webb, so he could take care of the science," and this is a very true statement still to this day. Moreover, she is a gracious hostess for the numerous graduation and going-away parties at their house. She also accompanies her husband to many conferences and social events. Going out to dinner with the Webb group and a visiting speaker or faculty recruit inevitably becomes a detailed scientific discussion. Through all of these Page has the same smile and pleasant demeanor. She was once asked after a particularly long debate how much of the scientific understanding she had picked up over the years. She replied, "Oh, not much." However, her modesty is often proved wrong when she comes out with a witty comment about the scientific issue under discussion.

It is not possible to interact with Webb very long before the subject of sailing comes up. Some of the best outings of the Webb research group were the "studies of wave dynamics" on Cayuga Lake. Webb learned to sail when he was 12 and in fact met his wife sailing. He adds that he started sailing rather late in life because Page started sailing at age two! The Webb family was always active in competitive sailing, and they are still winning regattas. They have reduced the number of competitions they enter, which allows more time to enjoy cruising the Atlantic coast with their family and friends.

Webb's initial research area at Cornell was on the physical properties of superconducting metals including perfect nanocrystals, and the study of critical phenomenon. His interest in biological systems started when Elliot Elson joined the Chemistry Department as an assistant professor. Elliot was trained in nucleic acid chemistry, and at the time very little was known about the nucleus, or mechanisms of transcription and replication. Elliot suggested that he and Webb should collaborate on looking at the fluctuations in DNA absorption bands, which were known to shift when DNA was denatured. Webb's experience using quasi-elastic light scattering on systems with continuous phase transitions could be directly applied to the study of such fluctuating systems. Webb pointed out that, unfortunately, the DNA absorption fluctuations could not be measured. However, the collaborators soon discovered that the fluorescent drug ethidium forced the two double strands of the DNA apart, and the fluctuations of this process could be measured. This approach became fluorescence correlation spectroscopy (FCS), and started Webb on the road in biological physics.

Webb's journey through biological physics has served all of us very well. In particular, the field of quantitative fluorescence microscopy has been greatly enhanced by the research done in his lab. Techniques that were invented or significantly developed there include fluorescence photobleaching recovery (also called FRAP), FCS, single-particle tracking on cell surfaces, microinterferometry for picometer displacement measurement, optical trapping to measure picoNewton forces, confocal microscopy, two-photon excitation (also called multiphoton microscopy or MPM), and other nonlinear microscopies. It should be emphasized that this work was not at the "gee whiz" level, but was always carried through until a detailed theoretical and experimental understanding was achieved. These accomplishments are all well described in the primary literature and many review articles.

The breadth and depth of the direct contributions of the Webb lab to biological physics are impressive. However, what might be even more impressive is Webb's indirect contribution through the many students and postdocs who have gone on to independent success. More than 50 graduate students have completed their PhD thesis work under Webb's direction, and there have been a similar number of postdocs who trained in the Webb lab. The alumni include faculty members and department chairs at Boston University, California-San Diego, Duke, Harvard, Maryland, Massachusetts, Michigan, MIT, New Mexico, Pennsylvania, Penn State, Princeton, Rhode Island, Rochester, Stanford, Texas, Vanderbilt, Yale, and Cornell, directors of Max-Planck Institute departments and large research divisions at Exxon and Bell Labs, and numerous staff members at national labs and corporate research labs.

It is probably impossible to define what explains Webb's success in mentoring his research group, but several characteristics come to mind. His research group seldom lacked for resources, which encouraged people to take chances on new 
ideas and approaches. Importantly, though, lab members had to convince Webb that their idea was solid before he would give the green light to proceed. Because of his desire to understand the experiments in rigorous detail, it was often much more difficult to convince Webb about the experiment than it was to convince reviewers of the resulting grant applications or manuscripts. As a result, the track record of grants and papers from the Webb lab is superb. While the group members sometimes felt that the rigorous detail required by Webb was a bit much at the time, almost all of them later realized that this prepared them for their future trials during job interviews, grant applications, and manuscript submittals. A second characteristic is Webb's willingness to facilitate independent thought and action in his group members. From his earliest days at Cornell, he had a sign in his office that read, "Thou shall not grab screwdrivers out of graduate student's hands." There is complete unanimity among Webb group alumni that he always adhered to this rule. He often said that "one doesn't have to turn the knobs oneself to do a good experiment," and he believes in the strong educational component of students doing experiments themselves. Because Webb lived close to the lab, though, it occasionally fell to him to look after an experiment during bad storms, when the students and postdocs could not make it in. These requests came only with great trepidation, although most lab alumni agree that Webb's interactions with the equipment left no permanent damage.

Finally, Webb has always taken care to acknowledge and thank those people in his research group who have done the work. He has always been rightfully proud of his research group and its alumni, and in his recent award lectures, he has spent significant effort thanking the group and pointing out the various accomplishments of its individual members. The one unfortunate side effect of having such a large and successful group is that the slide which contains all the group members and collaborators requires such a small font! It should be added that Webb is also extremely supportive of the lab alumni after they have left the lab.

Many years ago, he considered retiring, but as he says, "everything we are trying in the lab ends up working so well, that it is just too exciting to think about stepping away from it now." In 1990, Webb did "retire" to full-time research status, which released him from classroom teaching duties and allowed him to concentrate on his research.

Webb has been honored many times and in many ways for his research and training accomplishments. He was elected to the National Academy of Engineering in 1993 and to the National Academy of Science in 1995. He is a fellow of the American Physical Society (APS), the American Association for the Advancement of Science, and the Biophysical Society. $\mathrm{He}$ is also a founding fellow of the American Institute of Medical and Biological Engineers and an elected member of the American Academy of Arts and Sciences. He won the APS Biological Physics Prize in 1990, the Ernst Abby Lecture Award in 1997, the Michelson-Morley Award in 1999, the Rank Prize for Opto-electronics in 2000, and the Jablonski Award Lecturer in 2001, and was chosen as the national lecturer for the Biophysical Society annual meeting in 2002. His varying research contributions cannot be justly summarized here, but this special section of the Journal of Biomedical Optics is one more way to recognize and thank Prof. Webb for his tremendous contribution to biological physics in general and the field of biomedical optics in particular.

David W. Piston, Vanderbilt University

Elliott Elson, Washington University Special Section Guest Editors

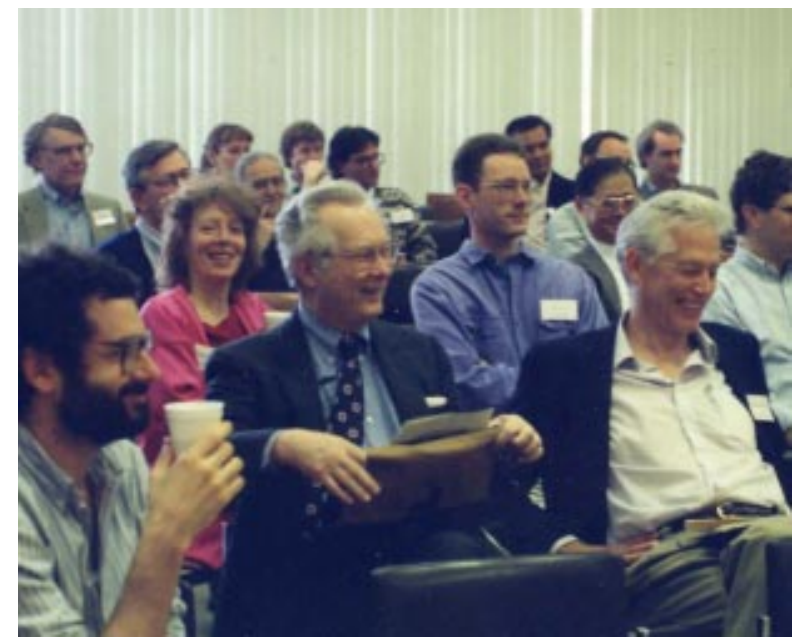

Watt Webb (center) at a seminar in his accustomed front-row seat. Here, he is surrounded by colleagues and former lab members at the Festschrift celebrating two-thirds of a century in 1994. 